\title{
STUDENTS' OPEN-ENDED PROBLEM SOLVING STRATEGY BASED ON VISUAL-SPATIAL AND LOGICAL-MATHEMATICAL INTELLIGENCE
}

\author{
Maulidna Wahyu Pratiwi \\ Mathematics Education, Faculty of Mathematics and Natural Sciences, Universitas Negeri Surabaya \\ e-mail: maulidnapratiwi@mhs.unesa.ac.id \\ Rooselyna Ekawati \\ Mathematics Education, Faculty of Mathematics and Natural Sciences, Universitas Negeri Surabaya \\ e-mail: rooselynaekawati@unesa.ac.id
}

\begin{abstract}
Problem solving and intelligence are connected each other. Every student has their own different intelligence. Intelligence affect students' problem solving strategy. This research aimed at describing the strategy of geometry open-ended problem solving of visual-spatial and logical-mathematical student. This research includes as descriptive research with qualitative approach. The research subjects consists of two students which are one student with visual-spatial and one student with logical-mathematical intelligence. The result shows that student of visual-spatial can understand and solve the problem, however lack to pay attention to the word description, while student of logical-mathematical can solve the problem with attend all of the information as well. In solving problem, student of visual-spatial and logical-mathematical can connect the given information to gain new information, which is that strategy called as logical reasoning strategy. Then, student of visual-spatial and logical-mathematical use the known formula to gain new equation, which is called as write an equation strategy. At the last solution, student of visual-spatial disposed to use table which is called as draw a picture or model strategy. While student of logical-mathematical disposed to do try and error to get the solution, which is called guess and check strategy.

Keywords: strategy of problem solving, geometry open-ended problem, visual-spatial intelligence, logicalmathematical intelligence
\end{abstract}

\section{INTRODUCTION}

Nowadays, mathematics is important in teaching and learning. Uno (2009) defined that there are branches of mathematics, they are arithmetic, algebra, analysis, and geometry. One of the important material talk about geometry. Thus, geometry is needed to be taught to the students. Walle (2001) defined about the reasons why geometry need to be taught such as geometry can be found in many visualization, geometry can develop students' problem solving ability, geometry is used in daily life by peoples, and geometry is enjoyable. By studying about geometry, students' ability in solving problem can be developed.

Problem solving defined as a tool to think which have steps (Posamentier and Krulik, 2009). There are four steps of problem solving: (1) understanding problem, (2) device a plan, (3) carry out the plan, and (4) looking back (Polya, 1973). While device a plan, will be determined the strategy that will be used. According to Walle (2013), student will choose a strategy as a problem solving. But, not all strategy are appropriate with the problem. Aydogdu (2014) defined that there are some factors which affect problem solving, but the most important is to use the best strategy. Strategy is stated as an appropriate set of step in solving a problem which different appropriate set of step are possible (Schuun, 2005). Thus, students must have a best strategy in ways to get a correct solution.

Based on Rusyda (2017), the level achievement of geometry is low than others material such algebra and arithmetic. Based on the observation in senior high school, researcher found that students get any difficulties in study mathematics especially about geometry which have affected on their final exam. According to those research, researcher indicate that student get difficulties in solving about geometry problem.

There are two kinds of problems, closed-ended and open-ended problem. Kwon et al (2006) stated that openended as a problem that have many differences solution possibilities. By giving open-ended geometry problem, hoped that students can apply a unique methods in order to solve problem. According to Cakir et al (2016) shows that teaching and learning by using open-ended question, students tried to use new strategy in order to solve the given problem.

Besides that, there is an ability which have affected in solving problem called intelligence. Rahbarnia (2014) defined that there is correlation between problem solving 
and intelligence. Had defined that visual-spatial and logical-mathematical intelligence have a high correlation in mathematics problem solving. According to those, researcher are interested to study about students' problem solving strategy in geometry open-ended problem based on visual-spatial intelligence and logical-mathematical intelligence.

\section{METHODS}

The data analysis will be presented as descriptive qualitative that aims to describe students' strategy in solving geometry open-ended problem. The research subject were two eighth grade students at MTs Negeri 1 Kediri. This research were obtained of two students with criteria: 1. Student of visual-spatial intelligence, 2. Student of logical-mathematical intelligence.

The test that used in this research were multiple intelligence test based on Howard Gardner which had developed by Chislett and Chapman (2005) to determine the students' dominant intelligence type and the students' level of mathematics ability test that were formed of five question of National Exam of Junior High School of the Year 2017/2018 which related to material in grade VII. The two groups of visual-spatial and logical-mathematical had given a level of mathematics ability test. The students that have an equivalent level of mathematical ability with the standard value were $\geq 75$ and the difference were not more than 5 point with a scale of 100 , have been followed to geometry open-ended problem solving test. The test related to geometry open-ended problem is a problem which were formed by rectangular problem. This test were given and completed individually by the subject within 40 minutes.

The students that have tendency in using some strategy and that have the best answer will be selected as a subject of research. The two selected subjects were interviewed by using interview guidance in order to gain deeper information of students' strategies in geometry open-ended problem solving. The result were analyze by data reduction, display, and conclusion.

\section{RESULT AND DISCUSSION}

The research was done in VIII-A and VIII-I grade of MTs Negeri 1 Kediri on $15^{\text {th }}$ April 2019 for intelligence identification test, $16^{\text {th }}$ April 2019 for level mathematics ability test and geometry open-ended test, then $29^{\text {th }}$ April 2019 for interview test.

By identifying multiple intelligence test, there were 20 student that have visual-spatial and logical-mathematical intelligence. Then, those students had followed in mathematics ability test. There were 17 students that included in the standard value then will be followed to problem solving test.
To describe the strategy that used, there are classification of strategies such as.

Table 1. Indicators of Proble Solving Strategies

\begin{tabular}{|c|c|c|}
\hline $\begin{array}{c}\text { Indicator of } \\
\text { Problem } \\
\text { Solving } \\
\text { Strategy }\end{array}$ & Code & Description \\
\hline $\begin{array}{l}\text { Look for } \\
\text { pattern }\end{array}$ & M-1 & $\begin{array}{l}\text { Organize the given } \\
\text { information, then find the } \\
\text { pattern based on the given } \\
\text { information }\end{array}$ \\
\hline $\begin{array}{l}\text { Draw a } \\
\text { picture and } \\
\text { model }\end{array}$ & M-2 & $\begin{array}{l}\text { Draw the visual representation } \\
\text { such as picture, table, graphic, } \\
\text { diagram, or sketch }\end{array}$ \\
\hline $\begin{array}{l}\text { Formulate an } \\
\text { equivalent } \\
\text { problem }\end{array}$ & M-3 & $\begin{array}{l}\text { Change the equivalent problem } \\
\text { by simplifying the given } \\
\text { number }\end{array}$ \\
\hline $\begin{array}{l}\text { Modify } \\
\text { common } \\
\text { problem }\end{array}$ & M-4 & $\begin{array}{l}\text { Make the common problem by } \\
\text { using particular example }\end{array}$ \\
\hline $\begin{array}{l}\text { Write } \\
\text { effective } \\
\text { symbols }\end{array}$ & M-5 & $\begin{array}{l}\text { Change problem into symbolic } \\
\text { written, then find the } \\
\text { correlation }\end{array}$ \\
\hline $\begin{array}{l}\text { Write an } \\
\text { equation }\end{array}$ & M-6 & $\begin{array}{l}\text { Make an equation which form } \\
\text { open statement from the given } \\
\text { information }\end{array}$ \\
\hline $\begin{array}{l}\text { Divide into } \\
\text { case }\end{array}$ & M-7 & $\begin{array}{l}\text { Divide the problem into small } \\
\text { cases }\end{array}$ \\
\hline $\begin{array}{l}\text { Work } \\
\text { backward }\end{array}$ & M-8 & $\begin{array}{l}\text { Start from the final result then } \\
\text { work backward to gain the } \\
\text { starting condition }\end{array}$ \\
\hline $\begin{array}{l}\text { Argue by } \\
\text { contradiction }\end{array}$ & M-9 & $\begin{array}{l}\text { Consider the false statement } \\
\text { and take contradiction } \\
\text { statement by using indirectly } \\
\text { method }\end{array}$ \\
\hline $\begin{array}{l}\text { Count for all } \\
\text { possibilities }\end{array}$ & M-10 & $\begin{array}{l}\text { Count all possible answer to get } \\
\text { the correct answer }\end{array}$ \\
\hline $\begin{array}{l}\text { Logical } \\
\text { reasoning }\end{array}$ & M-11 & $\begin{array}{l}\text { Determine information based } \\
\text { on the given information to get } \\
\text { the new information in solving } \\
\text { problem }\end{array}$ \\
\hline $\begin{array}{l}\text { Guess and } \\
\text { check }\end{array}$ & M-12 & $\begin{array}{l}\text { Try and error the possible } \\
\text { answer to get the appropriate } \\
\text { solution }\end{array}$ \\
\hline $\begin{array}{l}\text { Organizing } \\
\text { data }\end{array}$ & M-13 & $\begin{array}{l}\text { Organize data by using table or } \\
\text { pattern to gain other possible } \\
\text { solution }\end{array}$ \\
\hline $\begin{array}{l}\text { Consider } \\
\text { extreme case }\end{array}$ & M-14 & $\begin{array}{l}\text { Consider the possible extreme } \\
\text { case in the problem which had } \\
\text { been the key of the problem }\end{array}$ \\
\hline
\end{tabular}

Subject with visual-spatial intelligence (VS) 
Here are the results of geometry open-ended problem solving of visual-spatial student.

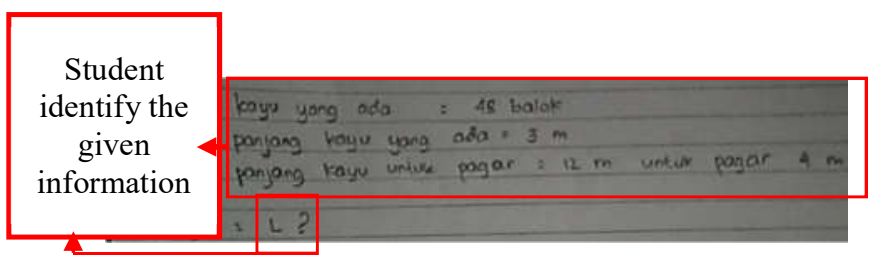

Figure. 1 Problem Solving Strategy of VS

Based on the answer sheet (Figure. 1), VS can understand the problem, it can be seen that VS write the information in the given problem. Besides that, VS write the given question of the problem. According to the answer sheet, VS did not pay attention to the description and disposed to pay attention to the information which related to number and picture.

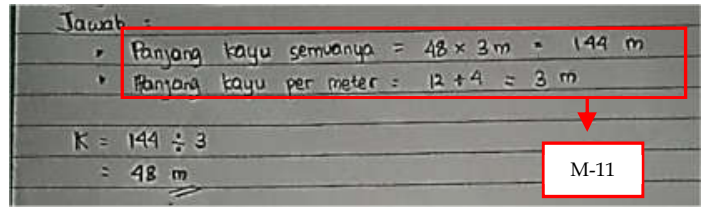

Figure. 2 Problem Solving Strategy of VS

At the first step (Figure. 2), VS connected the given information to gain new information that is determining the total woods that have bought and the length of the wood that needed to make a meter of fence. After that, VS determined the circumstance of the area by dividing the total of wood with the needed woods. That strategy called as logical reasoning (M-11) which is gaining new information from the given information to solve the problem.

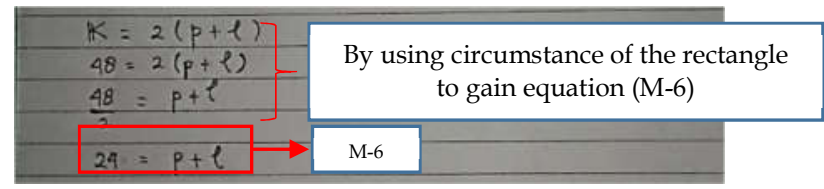

Figure. 3 Problem Solving Strategy of VS

From the second strategy (Figure. 3), VS used a strategy that gained from the known formula that is circumstance of rectangle. From that formula, have gained new equation with two variables that are length and width. That strategy called as make an equation strategy (M-6) that make an open statements from the given information.

At the last strategy (Figure. 4), VS made a table that used to organize the possibility of the maximum area from the organized length and width. That strategy called as make a picture or model strategy (M-2). Even thought, VS did not know that with same length and width, will be gotten the higher area. At the last solution, VS wrote a conclusion related on the question above.

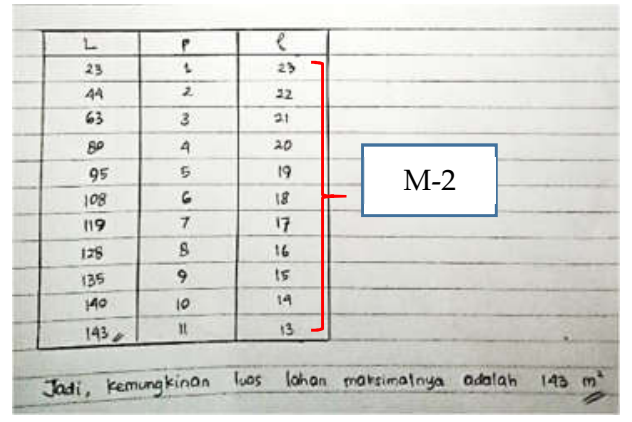

Figure. 4 Problem Solving Strategy of VS

\section{Subject with logical-mathematical intelligence (LM)}

Here are the results of geometry open-ended problem solving of logical-mathematical student.

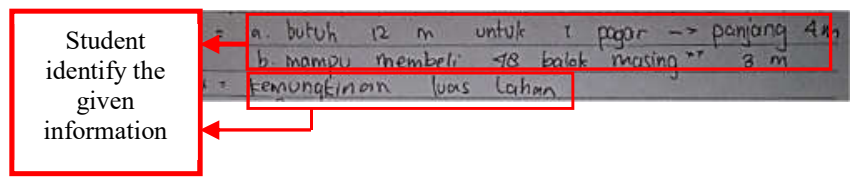

Figure. 5 Problem Solving Strategy of LM

Based on the answer sheet (Figure. 5), LM understood the problem, it can be seen that LM write the information in the given problem. LM write the given question of the problem. According to the answer sheet, LM paid attention to the all information which related to description and number.

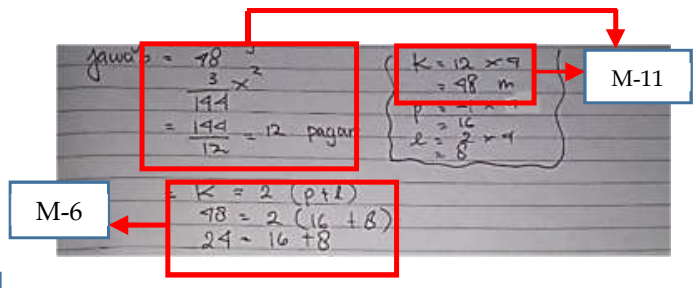

Figure. 6 Problem Solving Strategy of LM

At the first step (Figure. 6), LM connected the given information to gain new information that is determining the total woods that have bought and how many fence that can be formed by dividing the total woods and the length of wood that needed to make a design of fence. After that, he determined the circumstance of the area by multiplying the length of a design and the fences that formed. That strategy called as logical reasoning (M-11) which is gaining new information from the given information to solve the problem.

The next strategy that LM used (M-6) is called as make an equation from circumstance of rectangle. That equation have gotten from the information that he gained before.

At the last strategy (Figure. 4), LM tried to trial and error to find the possibility of the maximum area from the length and width by changing the length and the width of the area until he get the highest number. That strategy called as guess and check strategy (M-12). LM have known 
that with same length and width, will be gotten the higher area. At the last solution, LM wrote a conclusion related on the question above.

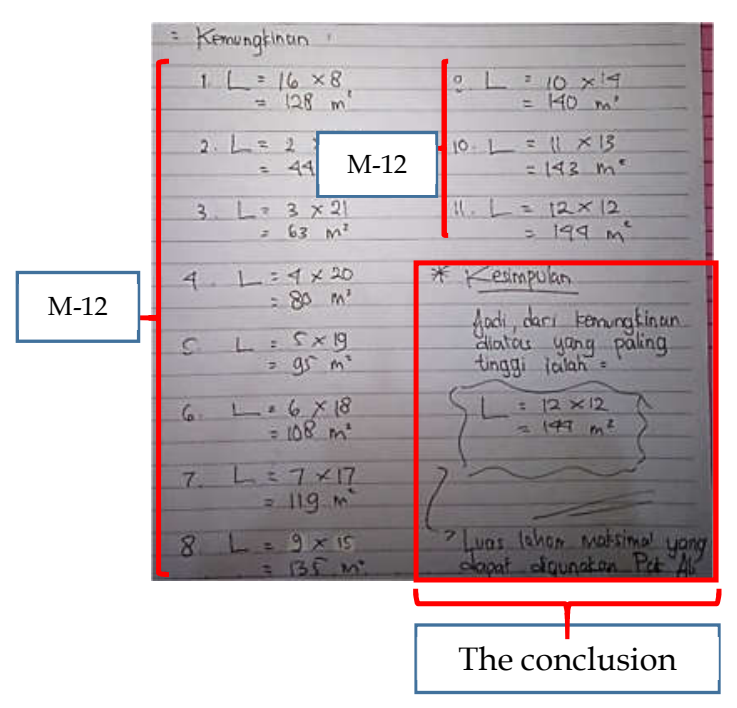

Figure. 7 Problem Solving Strategy of LM

\section{Discussion}

According to the theories, student of visual-spatial and logical-mathematical intelligence are potential to understand the geometry problem by using some of strategies based on their dominant intelligence. Armstrong (2013) defined that one of criteria logical-mathematical is using logical reasoning strategy in solving problem. It appropriate with the test result that student of logicalmathematical also use logical reasoning strategy in problem solving. But at the practise found that student with visual-spatial intelligence are also tend to use logical reasoning strategy.

The other strategy that used by visual-spatial and logical-mathematical student are make an equation from the circumstance rectangle formula. From that formula, visual-spatial and logical-mathematical student are able to gain new equation in order to solve the next strategy.

There is difference strategy that are used by visualspatial and logical-mathematical student. Student of visualspatial intelligence tend to make table in order to get the solution of maximum area. That strategy included as draw a picture or model strategy. It is in line with Yaumi (2012) that defined that the characteristic of visual-spatial intelligence are able to make graphic, diagram, and table. While the student with logical-mathematical intelligence tend to use guess and check strategy to get the maximum area.

\section{CONCLUSION AND SUGGESTION}

\section{Conclusion}

Based on the research data and discussion that have been described, it can be concluded that the strategy of geometry open-ended problem solving of students' visual-spatial and logical-mathematical intelligence as follows.

1. Student of visual-spatial intelligence is able to understand the problem. But visual-spatial student did not pay attention to the description information, and tend to the number information. Strategy of problem solving that used by student of visual-spatial intelligence is logical reasoning to gain new information from the given information. Then, visualspatial student make an equation strategy from the known formula. At the last, visual-spatial student use table which is called draw a picture or model strategy.

2. Student of logical-mathematical intelligence is able to understand the problem. Strategy of problem solving that used by logical-mathematical student is logical reasoning strategy to gain new information from the given information. Then, logical-mathematical student make an equation strategy from the known formula. At the last, logical-mathematical student use guess and check strategy to get the solution.

\section{Suggestions}

Based on the research data, analysis, and conclusion that have been done, there are several suggestion that can be mentioned as follows.

1. Teacher should device the teaching and learning process to be more interest in order to make students with differences intelligence can be optimize their knowledge.

2. Teacher should device the teaching and learning process by using open-ended problem in order to increase their ability to use different strategy.

\section{REFFERENCES}

Amstrong, T. (2013). Kecerdasan Linguistik di Dalam Kelas. Terjemahan Dyah Widya Purbaningrum. Jakarta: PT Indeks.

Aydogdu, M. Z. (2014). A research on geometry problem solving strategies used by elementary mathematics teacher candidates. Journal of educational and instructional studies in the world. Vol. 4 Issue 1

Cakir, H. et al. (2016). The Use of Open Ended versus Closed Ended Questions in Turkish Classsrooms. (Online)

(http://dx.doi.org/10.4236/ojml.2016.62006, accessed on $15^{\text {th }}$ Juni 2019) 
Chislett, V and Chapman, A. (2005). Multiple Intelligence Test- based on Howard Gardner's MI Model (Online) (http://www.businessball.com, accessed on $15^{\text {th }}$ Mei 2018).

Kwon, O. N., et al. (2006). Cultivating Divergent Thinking in Mathematics Through Open-Ended Approach. Journal Asia Pacific Education Review. Vol. 7, No. 1, 51-61.

Polya, G. (1973). How to Solve it: A New Aspect of Mathematical Method. New Jersey: Princeton University Press.

Posamentier A. S. and Krulik S. (2009). Problem-Solving in Mathematics Grades 3-6, Powerful Strategies to Deepen Understanding: United States of America.

Rahbarnia, F. et al. (2014). A Study on the relationship between multiple Intelligences and mathematical problem solving based on Revised Bloom Taxonomy. Journal of Interdisciplinary Mathematics. 17: 2, 109-134, DOI: https://doi.org/10.1080/09720502.2013.842044.
Rusyda, N. A. et al. (2017). A Cognitive Analysis of Students` Mathematical Problem Solving Ability on Geometry. International Conference on Mathematics and Science Education. Doi :10.1088/17426596/895/1/012081.

Schuun, C. D. (2005). Expertise in Ill Defined ProblemSolving Domains as Effective Strategy Use. Journal on University of Pittsburgh Vol 8 Issu 33.

Uno, H. (2009). Orientasi Baru dalam Psikologi Pembelajaran. Jakarta: Bumi Aksara.

Walle, J.A. (2001). Geometry Thinking and Geometry Concept: In Elementary and Middle School Mathematics, Teaching Developmentally, 4th ed. Boston: Allyn and Bacon.

Walle, J.A. et al. (2013). Teaching Through Problem Solving: In Elementary and Middle Mathematics, Teaching Developmentally, 8th edition. Boston: Pearson Education, Inc.

Yaumi, M. (2012). Pembelajaran Berbasis Multiple Intellegences. Jakarta: Dian Rakyat. 